\title{
A MESTERSÉGES INTELLIGENCIA (AI) AZ EGÉSZSÉG SZOLGÁLATÁBAN
}

\section{ARTIFICIAL INTELLIGENCE (Al) IN THE SERVICE OF HEALTH}

\author{
Dr. Devosa Iván Ph.D. ${ }^{1^{*}}$, Dr. Grósz Tamás Ph.D. ${ }^{2,3}$, Dr. Kardos Péter Ph.D. ${ }^{3}$ \\ ${ }^{1}$ Egészségtudományi Kutatómühely, Tanítóképző Főiskolai Kar, Károli Gáspár Református Egyetem, \\ Magyarország \\ ${ }^{2}$ Aalto University Helsinki, Finland \\ ${ }^{3}$ Természettudományi és Informatikai Kar, Szegedi Tudományegyetem, Magyarország \\ https://doi.org/10.47833/2020.3.CSC.001
}

\section{Kulcsszavak:}

Mesterséges Intelligencia

Konvolúciós Neuronháló

Parkinson

Tüdőszürés

\section{Keywords:}

Artificial Intelligence

Convolutional Neural Network

Parkinson

Lung screening

\section{Cikktörténet:}

Beérkezett

Átdolgozva

Elfogadva

2020. október 28

2020. október 30

2020. október 31.

\section{Összefoglalás}

A Mesterséges Intelligencia lehetőségei korlátlanok, pontosabban annyira korlátoltak, amennyire az annotált anyagok mennyisége. A medikális rendszerek alkalmassá tehetők akár a beszédből történő Parkinson szürésre, vagy a képalkotó diagnosztikai eszközökböl nyert információk feldolgozásával a tüdőszürés automatizálására. Mindehhez az itt ismertetett UNET struktúra lehet az egyik hatékony megoldás.

\begin{abstract}
The possibilities of Artificial Intelligence are limitless, more precisely as limited as the amount of annotated materials. Medical systems can be adapted to either Parkinson's screening from speech or to automate lung screening by processing information obtained from imaging diagnostic tools. For all this, the U-NET structure described here can be one of the effective solutions.
\end{abstract}

\section{Bevezetés}

Jelen tanulmányunkban arra keresünk válaszokat, hogy az informatikában jelenleg is zajló, forradalmi fejlődést hozó mély neuronhálók és Mesterséges Intelligencia (Al) fejlesztések, milyen lehetőségeket tartogat az orvostudomány számára. Természetesen egyetlen tanulmány nem ölelheti fel a teljes kérdéskört, de igyekeztünk több olyan területre is felhívni az olvasók figyelmét melyre, mint a téma kutatóinak nagyobb rálátásunk van, és igen ígéretesnek tűnik a jövőt illetően.

2006-os megjelenésük óta a mesterséges mély neuronhálók (Deep Neural Networks) forradalmasították a mesterséges intelligenciát. Köszönhetően ennek az új eszköznek, a mély tanulás (Deep Learning) több területen is rendkívül sikeresen került alkalmazásra. Ezen területek közül a képfeldolgozásban és beszédfelismerésben ma már az ezekre épülő rendszerek kereskedelmi forgalomban is megjelentek. A mély tanulás sikeressége mögött két fontos faktor figyelhető meg: egyrészröl rendkívül megnövekedett a rendelkezésünkre álló számítási kapacitás, amely lehetővé tette a bonyolultabb és időigényesebb tanuló algoritmusok használatát. A másik rendkívül fontos jelenség, hogy ma már több feladathoz rendelkezésünkre áll nagy mennyiségü címkézett (annotált) adat, amelyet felhasználva pontosabb modelleket tudunk tanítani.

\footnotetext{
* Kapcsolattartó szerző. Tel.: +36 303806264

E-mail cím: ivan@devosa.hu
} 
Az utóbbi pár évben megjelentek az első kísérletek a mesterséges intelligencia alkalmazására az orvostudományban, ám ezek még csak kezdeti rendszerek, melyek pontossága nem feltétlenül éri el azt a szintet, amit valós alkalmazásuk esetén elvárnánk. A magyarázat erre rendkívül egyszerü, jelenleg nem áll rendelkezésünkre kellő mennyiségű címkézett adat, így a betanított rendszerek minősége nem feltétlenül éri el az orvostudományban megkövetelt szintet.

$A z$ egészségügyben hatalmas mennyiségű digitális adat keletkezik nap mint nap, amelyet jelenleg emberi erővel dolgoznak fel. Célunk egy olyan rendszer kifejlesztése, amely ezt a folyamatot megkönnyíti azáltal, hogy az orvos számára hasznos információt nyer ki a páciens adataiból, esetlegesen javaslatot tesz a diagnózisra. Egy ilyen rendszer kifejlesztéséhez szükségünk van nagy mennyiségű egészségügyi adatra és együttműködésre az orvosok részéről, hiszen a mesterséges neuronhálók betanításához a terület specifikus szaktudás nélkülözhetetlen.

\section{Korábbi fejlesztések}

Az elmúlt években több orvosi témájú kutatást is végeztünk, ezek célja, hogy orvosok által szolgáltatott adaton mesterséges intelligencia segítségével automatikus rendszereket tanítsunk, amik az orvosok munkáját megkönnyíthetik.

Az egyik fő kutatási irányunk a beszédfeldolgozás volt, ezen belül foglalkoztunk Parkinson betegek beszédének elemzésével illetve enyhe kognitív zavaros detektálásával. A Parkinsonos rendszerünk [1] lényege a betegség súlyosságának becslése volt (UPDRS-III érték), így segítve az orvosokat a kezelésben. A kidolgozott módszer segítségével lehetséges a páciens állapotának becslése néhány beszédfeladat elvégzése által, így könnyebben eldönthető az adott kezelés hatékonysága körülményes orvosi vizsgálatok nélkül. Hasonló módon kidolgoztunk egy automatikus módszert [2], amivel lehetővé válik az enyhe kognitív zavar detektálása csupán beszédből, ez a rendszer szürővizsgálatok során lenne alkalmazható. Sajnos mindkét rendszer csak limitált mennyiségü adaton lett tanítva, pontosan ezért a gyakorlatban való használata jelenleg nem reális cél, ehhez lényegesen több adatra lenne szükség és megfelelö klinikai kiértékelésekre.

2015 óta dolgozunk egy automatikus képelemző módszer kifejlesztésén is, amely alkalmas orvosi képfelvételeken, az ún. spektrális domain OCT (Spectral-Domain OCT, SD-OCT) képeken látható - aktivált mikrogliákra utaló - ún. hiperreflektiv pontok (HRD) detektálására és kvantitatív jellemzésére. Célunk, hogy egy mély neuronhálókat alkalmazó módszert fejlesszünk ki ennek a szemészeti problémának a megoldására [3]. Tapasztalataink szerint ebben a feladatkörben is a mély tanulás a legalkalmasabb megoldás. A képelemző rendszert időskori makuladegenerációs betegek kezelése során lehet alkalmazni a kezelés hatékonyságának objektív értékelésére [4].

\section{Tüdőszürés mély neuronhálókkal}

A tüdőszűrés során röntgenfelvételt készítenek a tüdőröl, illetve annak tartalmáról, valamint a tüdő környékén lévő szervekről, például a légcsőről. A tüdőszűrés meglehetősen fontos vizsgálat, mert a tüdőt, illetve a körülötte lévő szerveket érintő betegségek (például a tbc és a tüdőrák is) gyakran sokáig tünetmentesek, nem járnak különösebb problémákkal. Azonban minél korábban fedeznek fel egy-egy betegséget, annál nagyobb az esély arra, hogy a gyógyításra alkalmazott terápia hatékony legyen.

Az elkészült röntgenképeket jelenleg radiológusok vizsgálják meg, amely rendkívül sok időt és emberi erőforrást vehet igénybe. Ezen folyamat meggyorsítására és segítésére tervezünk egy mesterséges intelligenciát alkalmazó rendszert kifejleszteni, amelyet nagy mennyiségü adaton tanítunk szakértő radiológusok segítségével. A tervezett rendszer többféle módon segítheti az orvosok munkáját, egyrészről kijelölhet problémás területeteket a röntgenképen, amelyeket az orvosnak célszerü alaposabban megvizsgálni. A végső célunk, -habár az előbb említett funkció is rendkívül hasznos - hogy a rendszer képes legyen diagnózist is felállítani és azt elözetes javaslatként az orvos számára átadni. 


\section{Tervezett módszer}

Ahogy korábban említettük egy röntgenképeket elemző rendszert tervezünk kifejleszteni, ehhez tekintve, hogy jelenleg csak limitált mennyiségű tanítóadat áll rendelkezésünkre első lépésként egy tanító adatbázist tervezünk létrehozni.

Az adatbázisunkat egy közelmúltban publikussá tett adatbázishoz [5] hasonlóan tervezzük létrehozni, az adatbázis tartalmazni fog:

- röntgen képeket digitalizálva

- minden képen bejelölve a problémás terület

- minden képhez orvosi diagnózist.

Egy megfelelő méretű és minőségű adatbázis létrehozásához elengedhetetlenül fontos, hogy radiológusokkal müködjünk együtt, hiszen a későbbiekben tanított mesterséges intelligenciánk minősége jelentősen függ a tanítóadat minőségétől.

A tanítóadat összegyűjtése után egy megfelelő mély neuronháló struktúrát fogunk kikísérletezni, ez nagy valószínüséggel egy konvolúciós háló lesz U-NET [6] típusú struktúrával, amelyet az 1. ábra szemléltet. A problémás területek jelzéséhez egy dekonvolúciós kimeneti réteget fogunk használni, a diagnózis felállításához pedig egy osztályozó réteget. Egy megfelelő struktúra kialakítása után a tanító adatokat felhasználva jelenleg elérhető szoftverekkel könnyen betanítható a mesterséges neurális hálózat.

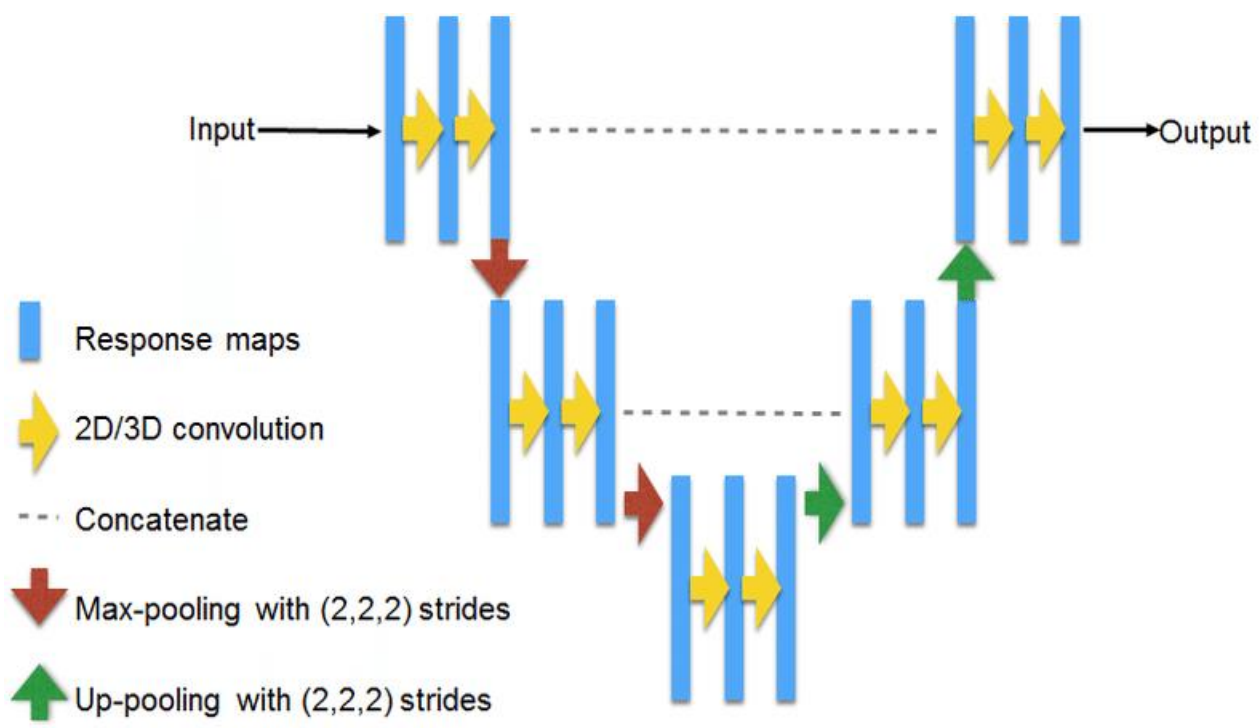

1. ábra: U-NET struktúra [6]

Input: bementi adat, Output: kimeneti adat, Response map: választérkép, 2D/3D convolution: 3D/3D konvolúció, Concatenate: összefüzés, Max-pooling with 2,2,2 strides: Max-összegzés (2,2,2) lépésben, Up-pooling with 2,2,2 strides: Felfelé-összegzés $(2,2,2)$ lépésben

A megfelelő struktúra kidolgozása után a betanított modellt korábban nem látott röntgenfelvételeken tervezzük kiértékelni, egyrészt, hogy megállapítsuk mennyire használható (mennyire pontos) a rendszer, másrészt pedig a mesterséges intelligencia válaszai alapján, szakorvosokkal konzultálva, finomhangolhatjuk a rendszert.

\section{További fejlesztések}

A fenti rendszer természetesen még nem alkalmas a mindennapi gyógyászatban történő alkalmazásra, ám terveink szerint a közeljövöben ez változni fog. A rendszer kialakításának kulcskérdése, hogy sikerül-e a közeljövőben megfelelö mennyiségü tanító adatot szerezni, mellyel a minél pontosabb tanítás megvalósítható.

A távolabbi jövő számtalan lehetőséget tartogat, így például a különböző neuronhálókból származó adatok egységesítése, mely lehetővé tenné, hogy átfogó diagnózis készüljön a betegröl 
egyetlen vizsgálat során, melynek diagnosztikai érteké felbecsülhetetlen, föleg az olyan betegségek esetén, melyeknél a korai diagnózis kardinális kérdés (például daganatok) a gyógyulás esélye szempontjából [7]. Biztosak vagyunk abban, hogy a fejlesztések eredményeképp kézelfoghatóan fog javulni az egészségi állapot mind egyéni, mind társadalmi szinten.

\section{Irodalomjegyzék}

[1] Grósz, T., Busa-Fekete, R., Gosztolya, G., Tóth, L.: Assessing the Degree of Nativeness and Parkinson's Condition Using Gaussian Processes and Deep Rectifier Neural Networks, Proc. Interspeech 2015, pp. 919-923. DOI: 10.21437/interspeech.2016-962

[2] Gosztolya, G., Tóth, L., Grósz, T., Vincze, V., Hoffmann, I., Szatlóczki, G., Pákáski, M., Kálmán, J.: Detecting Mild Cognitive Impairment from Spontaneous Speech by Correlation-Based Phonetic Feature Selection, Proc. Interspeech 2016, pp. 107-111. DOI: 10.21437/interspeech.2016-384

[3] Varga L., Katona M., Grósz T., Dombi J., Kovács A., Dégi R., Nyúl L.: Időskori makula degeneráció kvantitatív jellemzése SD-OCT képek automatikus elemzésével. XXVIII. Neumann Kollokvium konferencia-kiadványa, (NJSZT), 2015. pp. 43-48. DOI: 10.1007/978-3-319-93000-8_80

[4] Grósz, T., Devosa, I.: Artificial intelligence in medicine Archives Of The Hungarian Medical Association Of America $26: 1$ pp 50-51 (2018).

[5] Ronneberger, O., Fischer, P., Brox, T.: U-Net: Convolutional Networks for Biomedical Image Segmentation, CoRR, 2015. DOI: 10.1007/978-3-319-24574-4 28

[6] Wang X, Peng Y, Lu L, Lu Z, Bagheri M, Summers RM. ChestX-ray8: Hospital-scale Chest X-ray Database and Benchmarks on Weakly-Supervised Classification and Localization of Common Thorax Diseases. IEEE CVPR 2017.DOI: 10.1109/cvpr.2017.369

[7] Devosa, I., Grósz, T.: Az MI (AI) orvosi szempontból In: Iván, Devosa; Ágnes, Maródi; Zsuzsanna, Buzás; György, Bártfai (szerk.) International HEART 2019 Conference: program and abstracts of the conference (2019) pp. 57-58., 2 p. ISBN 978-615-5817-25-0 